\title{
Artificial Fertilization and Embryonic Development of Sinocyclocheilus grahami (Regan) from Dianchi Lake, China
}

\author{
Xiao-Fu Pan ${ }^{1}$, Xiao-Ai Wang ${ }^{1,2^{\star}}$, Li Ma ${ }^{3}$, Zai-Yun Li ${ }^{1}$, Xiao-Yong Chen ${ }^{1}$ and Jun-Xing Yang ${ }^{1}$ \\ ${ }^{1}$ State Key Laboratory of Genetic Resources and Evolution, Kunming Institute of Zoology, Chinese Academy of Sciences, Kunming, Yunnan 650223, China \\ ${ }^{2}$ University of the Chinese Academy of Sciences, Beijing 100049, China \\ ${ }^{3}$ Jeffery Lab at the University of Maryland, College Park, MD 20742, USA
}

"Corresponding author: Xiao-Ai Wang, State Key Laboratory of Genetic Resources and Evolution, Kunming Institute of Zoology, Chinese Academy of Sciences, Kunming, Yunnan, China, Tel: 86-871-65199886; Fax: 86-871-65199886; E-mail: xueaiw@126.com

Received date: March 07, 2014, Accepted date: April 05, 2014, Published date: April 15, 2014

Copyright: @ 2014 Pan XF, et al. This is an open-access article distributed under the terms of the Creative Commons Attribution License, which permits unrestricted use, distribution, and reproduction in any medium, provided the original author and source are credited.

\begin{abstract}
Sinocyclocheilus grahami, a troglophile species, is a cyprinidae fish endemic to Dianchi Lake, Yunnan, China. We have attempted the artificial propagation of $S$. grahami for several years and recorded the success of $S$. grahami artificial fertilization for six years and found that egg quality improved with enhanced broodstock management, with

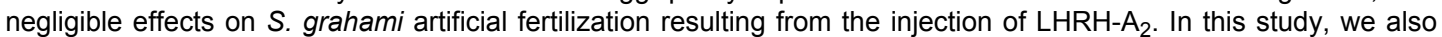
provide a comprehensive staging series of this species. The eggs have relatively large yolks $(1.8-2.2 \mathrm{~mm})$ and are strongly adhesive. The egg envelope is thick and transparent. The embryonic development of $S$. grahami can be divided into thirty stages based on morphological features visible using light microscopy. Stages can be further grouped into six periods: zygote, cleavage, blastula, gastrula, segmentation and hatching. Embryos hatched 144.0168.0 hours after fertilization (HPF). S. grahami embryonic development is generally similar to that of zebrafish (Danio rerio) and Anabarilius grahami but is relatively slower.
\end{abstract}

Keywords: Artificial fertilization; Embryonic development; Hatching time; Sinocyclocheilus graham

\section{Introduction}

Sinocyclocheilus grahami (Regan, 1904) is a troglophile species found only in Dianchi Lake, Yunnan, China. Historically, it was an economically valuable fish, but because of pollution and overharvesting, it has now been categorized as a second-class, stateprotected animal on major national wildlife protection lists [1] and endangered of China species red list, Vol. 1 red list [2]. Some studies of S. grahami, focusing on areas such as system phylogeny $[3,4]$ and population genetic structure [5], have been reported.

Artificial fertilization plays an important role in biodiversity protection and has long been used in freshwater fish, e.g. salmonids and cyprinids [6,7]. Studies of artificial fertilization are particular important in species that, like S.grahami, do not achieve spontaneous spawning in captivity, whose gametes must be hand-stripped and for which artificial fertilization is necessary to obtain fertilized eggs. Therefore, the fertilization conditions used in these species have a major impact on their hatcheries' production yield [8]. To further protect and study this valuable species, we attempted the artificial propagation of $S$. grahami for several years and succeeded in 2007 [9]. Currently, five hundred thousand larvae are propagated per year at the EFCC (Endangered Fish Conservation Center, Kunming Institute of Zoology, Chinese Academy of Sciences), and from 2009 to 2012, six hundred thousand fingerlings were returned to Dianchi Lake [10].

However, the aberration rate of $S$. grahami larva has increased with the frequency of artificial propagation, as evidenced by a variety of malformations. Adequate staging of embryonic development is important to obtain an accurate description of normal development and provides insight into abnormal embryonic growth and development. In addition, it is also valuable for the protection and production of endangered and economically important species [11,12]. However, the early embryonic development of $S$. grahami is poorly understood. Following our successful studies regarding cultivation and feeding [13], broodstock management, fecundity and the relationship between egg size and embryo survival ability [14], in this study, we focus on the morphological structures and malformation rate at different stages of $S$. grahami.

\section{Materials and Methods}

\section{Broodstock breeding and artificial fertilization}

The adult $S$. grahami fish were sorted from the Dianchi Lake of Yunnan Province, China (Figure 1) and cultured in EFCC. The broodstock breeding method has been carried out for every year according to Yang et al. [9].

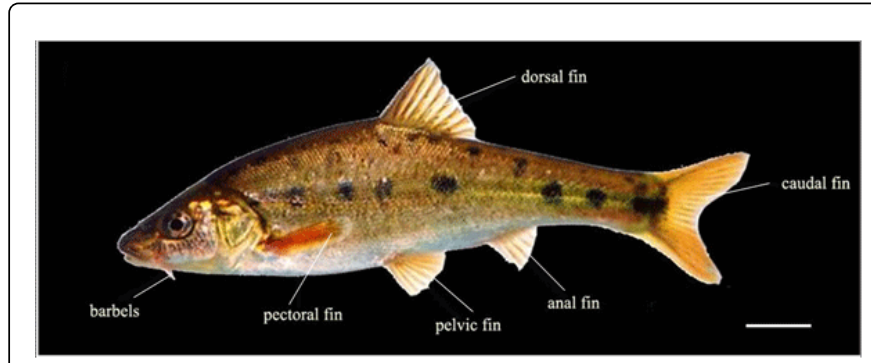

Figure 1: Adult fish of Sinocyclocheilus grahami. Scale bars $=1 \mathrm{~cm}$ 
Citation: Pan XF, Wang XA, Ma L,Li ZY, Chen XY, Yang JX (2014) Artificial Fertilization and Embryonic Development of Sinocyclocheilus grahami (Regan) from Dianchi Lake, China. J Biodivers Biopros Dev 1: 101. doi:10.4172/2376-0214.1000101

Page 2 of 6

Spawning was induced by an intramuscular injection of $0.1 \mathrm{mg} / \mathrm{kg}$

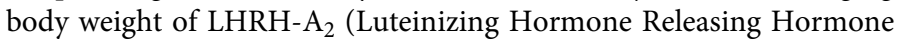
$\mathrm{A}_{2}$ ) and $0.1 \mu \mathrm{g} / \mathrm{kg}$ body weight of DOM (Domperidone), which is half the dose used for males [9]. The number of spawning fish induced by hormone was connected with condition of broodstock. If the broodstock lag eggs naturally, the number of spawning fish induced by hormone would decrease.

Newly fertilized $S$. grahami eggs were collected and cultured at $20^{\circ} \mathrm{C}$ at EFCC. Ten clutches of newly fertilized eggs from different females were collected each year between April 2007 and April 2012.

Rates of fertilization, hatching and malformation were calculated for each year. Fertilized eggs were counted at the end of the gastrula period after $45 \mathrm{~h}$ of incubation (stage 15) [15], and the fertilization rate was calculated as fertilized eggs / total number of eggs $\times 100$. After hatching, live larvae were counted and the hatching rate was calculated (hatched larval/fertilized eggs $\times 100$ ) [16]. Malformed larvae were also recorded during hatching periods in each observation, and the percentage of malformations larvae calculated (malformed larval / fertilized eggs $\times 100)[17]$.

\section{Embryonic development observation}

Embryonic development of $S$. grahami was divided into thirty stages. The stages were grouped into six periods: zygote, cleavage, blastula, gastrula, segmentation and hatching period. Stages from fertilization to hatching were named descriptively following the Danio rerio staging system [11], based on hallmark morphological features that are both developmentally significant and readily observed in live material under a dissecting microscope.

The eggs were staged according to their morphological characteristics following those of D. rerio [11] and Anabarilius grahami [12]. For each observation, ten eggs were examined carefully. The time for each stage was determined when at least half of the eggs observed had reached that stage; typically, more than $75 \%$ of the eggs reached the stage at the reported time. All images were taken with a Leica dissecting stereo-microscope.

\section{Results}

\section{S. grahami artificial fertilization and malformation}

The results of $S$. grahami artificial fertilization for six years are presented in Table 1. The percentage of fertilized eggs rapidly increased from $65.1 \%$ to $85.5 \%$ between 2007 and 2008. Although there was a slight decline in 2009 , fertilization rate gradually increased to $92.1 \%$ in 2012 . Similar to the fertilization rate, the hatching rate also increased from $32.4 \%$ in 2007 to $48.1 \%$ in 2012 ; however, the lowest rate was $30.8 \%$ in 2009 . Moreover, more than half of the fertilized eggs failed to hatch in each year.

\begin{tabular}{|l|l|l|l|l|l|l|}
\hline & $\mathbf{2 0 0 7}$ & $\mathbf{2 0 0 8}$ & $\mathbf{2 0 0 9}$ & $\mathbf{2 0 1 0}$ & $\mathbf{2 0 1 1}$ & $\mathbf{2 0 1 2}$ \\
\hline $\begin{array}{l}\text { Number } \\
\text { sampled eggs }\end{array}$ & 289 & 461 & 526 & 609 & 530 & 623 \\
\hline $\begin{array}{l}\text { Number } \\
\text { fertilized eggs }\end{array}$ & 188 & 394 & 422 & 518 & 456 & 574 \\
\hline $\begin{array}{l}\text { Fertilization } \\
\text { percentage (\%) }\end{array}$ & 65.1 & 85.5 & 80.2 & 85.1 & 86 & 92.1 \\
\hline
\end{tabular}

Table 1: Results of $S$. grahami artificial fertilization during 2007 and 2012.

Fertilization percentage $/ \%=$ number of fertilized eggs $/$ number of sampled eggs $\times 100$

Hatching rate $(\%)=$ number of hatching larval / number of fertilized eggs $\times 100$

Rate of malformation in hatching $(\%)=$ number of malformed larval / number of fertilized eggs $\times 100$

The rate of malformation in hatching increased with time and reached $24.2 \%$ in 2009 before gradually dropping to $12.5 \%$ in 2012 (Table 1). A variety of malformations were observed in $S$. grahami, such as spinal malformation (Figure 2A), yolk-sac malformation (Figure 2B) and thorax malformation (Figure 2C).
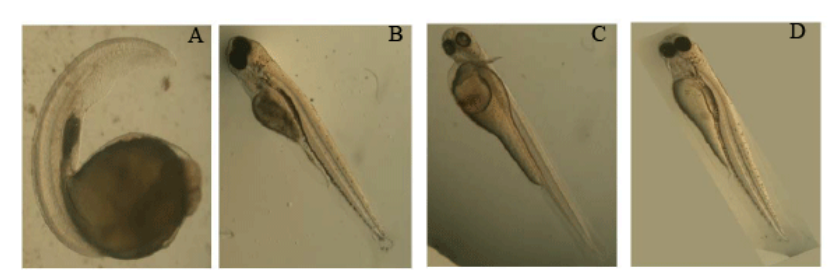

Figure 2: Normal and abnormal S. grahami larval.
A) spinal malformation $104 \mathrm{hpf}$
B) yolk-sac malformation $168 \mathrm{hpf}$
C) thorax malformation $130 \mathrm{hpf}$
D) normal body shape $168 \mathrm{hpf}$

\section{S. grahami developmental staging series}

Embryonic development of $S$. grahami took $168 \mathrm{~h}$ from fertilization. The durations of the zygote, cleavage, blastula, gastrula, segmentation and hatching periods are $1,4,17,23,51$ and $72 \mathrm{~h}$, respectively. The details are described below, and the corresponding timing is summarized in (Table 2).

\begin{tabular}{|l|l|l|l|l|}
\hline \multicolumn{2}{|l|}{ Stage } & Somites & $\begin{array}{l}\text { Hours post- } \\
\text { fertilization }\end{array}$ & Figure No. \\
\hline & Unfertilized & & $0: 00$ & \\
\hline 1 & Blastodisc & & $1: 00$ & $\begin{array}{l}\text { Figure 3A and } \\
\text { B }\end{array}$ \\
\hline 2 & Two-cell & & $1: 30$ & Figure 3C \\
\hline 3 & Four-cell & & $2: 15$ & Figure 3D \\
\hline
\end{tabular}


Page 3 of 6

\begin{tabular}{|c|c|c|c|c|}
\hline 4 & Eight-cell & & 3: 00 & Figure $3 \mathrm{E}$ \\
\hline 5 & Sixteen-cell & & 3: 45 & Figure $3 \mathrm{~F}$ \\
\hline 6 & Thirty-two-cell & & 4: 30 & Figure $3 G$ \\
\hline 7 & Sixty-four-cell & & 5: 15 & Figure $3 \mathrm{H}$ \\
\hline 8 & Early blastula & & 8: 15 & Figure $3 \mathrm{I}-\mathrm{K}$ \\
\hline 9 & Mid-blastula & & 16: 00 & Figure $3 \mathrm{~L}-\mathrm{O}$ \\
\hline 10 & Late blastula & & $22: 35$ & Figure $3 P, Q$ \\
\hline 11 & Pre-early gastrula & & $24: 25$ & Figure 3R \\
\hline 12 & Early gastrula & & 26: 05 & Figure 3S \\
\hline 13 & Pre-mid gastrula & & 28: 05 & Figure $3 \mathrm{~T}$ \\
\hline 14 & Mid-gastrula & & 40: 15 & $\begin{array}{l}\text { Figure } 3 U \text { and } \\
V\end{array}$ \\
\hline 15 & Late gastrula & & 45: 00 & $\begin{array}{l}\text { Figure } 3 W \text { and } \\
X\end{array}$ \\
\hline 16 & Early segmentation & & 45: 00 & Figure $4 \mathrm{~A}$ \\
\hline 17 & $\begin{array}{ll}\text { Brain } & \text { primordium } \\
\text { thicken } & \end{array}$ & 2 & $47: 30$ & Figure $4 \mathrm{~B}$ \\
\hline 18 & Blastopore closed & $4-8$ & 50: 30 & Figure $4 \mathrm{C}$ \\
\hline 19 & Otic vesicle formation & $10-16$ & 58: 30 & Figure 4D \\
\hline 20 & Brain regionalization & $16-19$ & 60: 00 & Figure $4 \mathrm{E}$ \\
\hline 21 & Optic lens completion & $19-22$ & $66: 50$ & Figure $4 \mathrm{~F}$ \\
\hline 22 & Heart beating & $23-27$ & 72: 20 & Figure $4 \mathrm{G}$ \\
\hline 23 & Pectoral fin bud & $30-34$ & 76: 00 & Figure $4 \mathrm{H}$ \\
\hline 24 & Retinal pigmentation & $34-36$ & 80: 00 & Figure $4 \mathrm{I}$ \\
\hline 25 & Internal ear formation & 44 & 96: 00 & Figure $4 \mathrm{~J}$ \\
\hline 26 & Tail wrapped past head & & 104: 00 & Figure $5 \mathrm{~A}$ \\
\hline 27 & $\begin{array}{l}\text { Formation } \\
\text { swimbladder }\end{array}$ & & 120: 00 & Figure 5B \\
\hline 28 & $\begin{array}{l}\text { Pectoral fin blood } \\
\text { circulation }\end{array}$ & & 130: 00 & Figure $5 \mathrm{C}$ \\
\hline 29 & Heart development & & 148:00 & Figure 5D \\
\hline 30 & Hatching competence & & 168: 00 & \\
\hline
\end{tabular}

\section{Cleavage period (60 $\mathrm{min}-5 \mathrm{~h} 15 \mathrm{~min})$}

After the first cleavage, the blastomeres divided synchronously at intervals of approximately $30-45 \mathrm{~min}$. The cleavage period includes the 2-, 4-, 8-, 16-, 32- and 64-cell stages (Figure 3C-H). Mitotic spindles can be observed as the disc cleaves to form two distinct cells (Figure $3 \mathrm{C})$. The second cleavage was also horizontal and resulted in a $2 \times 2$ array (Figure 3D) at approximately $135 \mathrm{~min}$. The third cleavage occurred in two separate planes and produced a $2 \times 4$ array lying sideby-side (Figure $3 \mathrm{E}$ ). Then, the rows were cleaved vertically in parallel planes to produce a $4 \times 4$ array of 16 cells (Figure 3F). The arrangements of cells at the 32 - and 64-cell stages were variable (Figure 3G-H). Until the 64-cell stage, the cell cycle time between cleavages was $255 \mathrm{~min}$, and subsequent cleavages became more irregular.

\section{Blastula period ( $5 \mathrm{~h} 15 \mathrm{~min}-22 \mathrm{~h} 35 \mathrm{~min}$ )}

By $5 \mathrm{HPF}$, approximately seven cleavages had occurred, and the embryo entered the blastula period. The blastula period was mainly divided into the early blastula, mid-blastula, and late blastula stages (Figure 3I-Q). The cells divided in an approximately synchronous manner during the early stages of the blastula period. However, after early blastula stage, no synchronicity in cell division was observed, the cell mound became more compact, and the embryo entered the midblastula transition (MBT) stage. The peripheral blastomeres around the rim of the cell ball fuse to form the yolk syncytial layer. The yolk cell bulged up towards the animal pole, creating a dome-like embryo shape, after which epiboly began. The blastula period ended when the blastoderm margin was at $30 \%$ of the entire distance between the animal and vegetal poles.

\section{Gastrula period ( $22 \mathrm{~h} 35 \mathrm{~min}-45 \mathrm{~h}$ )}

In the gastrula period, the morphogenetic cell movements of involution, convergence, and extension were observed and consequently generated the three primary germ layers and the embryonic axes (Figure 3R-X). Cell involution at approximately 50\% epiboly marked the onset of gastrula (Figure 3R). At this stage, half of the yolk cell was covered with the blastoderm progressing by epiboly. Then, the cells of the deep cell layer at the margin of the blastoderm involuted as the blastoderm folded back on itself, giving rise to the germ ring, a thickening of the blastoderm that could be observed in lateral views of the embryo. The germ ring was composed of two layers of cells: the outer epiblast and the inner hypoblast. The germ ring formed nearly simultaneously around the blastoderm rim (Figure 3S). Convergence movements then produced a local accumulation of cells at one position along the germ ring, the so-called embryonic shield, which marked the location of the future dorsal side of the embryo (Figure 3T). Epiboly remained at 50\% until the late shield stage. As soon as the shield had formed, epiboly restarted at a relatively constant rate until the blastoderm completely covered the yolk. As epiboly advanced, the shield became progressively less distinctive (Figure 3U, $\mathrm{V}, \mathrm{W})$. The dorsal blastoderm was now considerably thicker than the blastoderm in the rest of the embryo. At the tail bud stage (Figure $3 \mathrm{X}$ ), the yolk sphere was nearly covered by the thin blastoderm, leaving a small area around the vegetal pole (yolk plug) exposed, defining $100 \%$ epiboly. After epiboly was completed, the embryo developed a distinct thickening at its caudal end, which was the tail bud. At the end of gastrulation, the neural plate was already visible as a prominent thickening at the dorsal side, with the anterior presumptive brain region being particularly thick. 

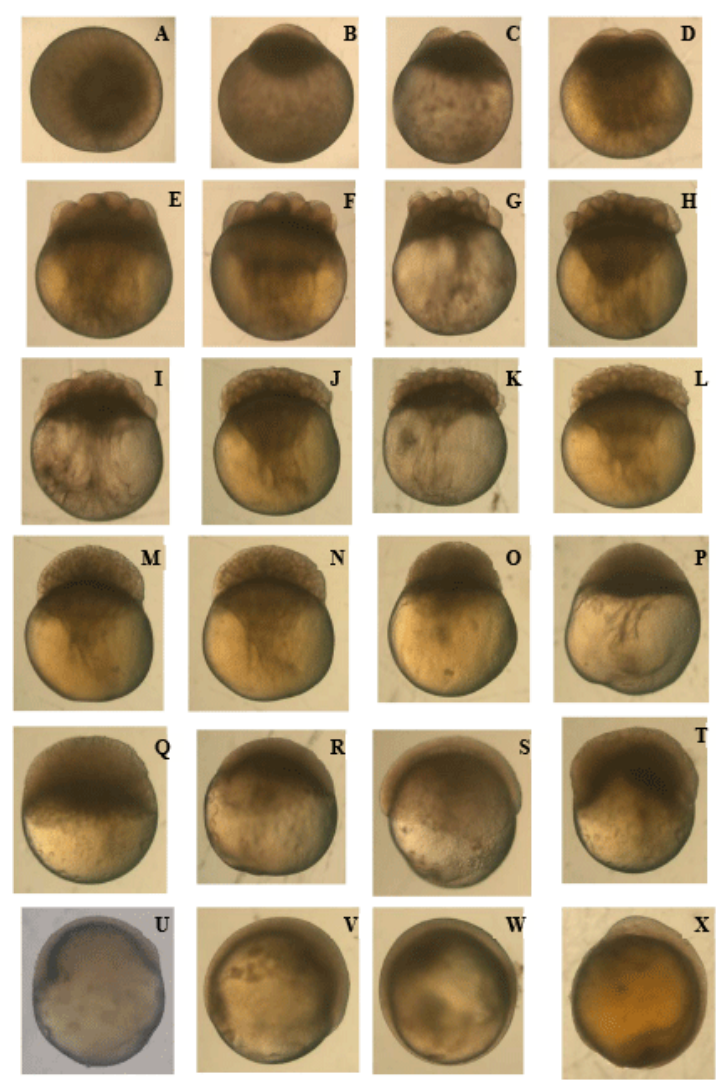

Figure 3: Embryonic development of $S$. grahami during the zygote, cleavage, blastula and gastrula periods.

\section{Segmentation period $(45 \mathrm{~h}-96 \mathrm{~h})$}

During the segmentation period, the most useful staging tool is the number of somites, which appear linearly with respect to time. During this period, tissues and organs differentiated from germ layers by cellular interactions. Moreover, the embryo elongated along the anterior-posterior axis, the tail bud grew longer and rudiments of the primary organs became apparent. Somite formation began at $47 \mathrm{HPF}$ in the central part of the embryonic body (Figure 4A). Somite numbers increased on average by one pair every hour until the 6somites stage, with the total number of somites reaching approximately 44 at $96 \mathrm{HPF}$. The brain primordium was now distinctively thickened into the neural keel at the 2-somites stage (Figure 4B). The optic vesicle was first distinguished at the 6-somites stage from a side view and became more clearly visible with a prominent horizontal crease at the 8 -somites stage (Figure 4C). During the early segmentation period, the brain rudiment was discernible from the spinal cord rudiment, based on its large size (Figure 4D). At this stage, however, the brain remained unstructured. With the extension of the tail rudiment, the otic placode was formed by thickening beside the hindbrain rudiment and the shape of somites in the anterior region changed from elliptical to $\mathrm{V}$-shaped (Figure $4 \mathrm{E}$ ). At the 22-somites stage, the yolk extension became clearly demarcated from the anterior yolk ball and elongated posteriorly with the extension of the trunk region. The lens placode appeared, and the otic placode hollowed into the otic vesicle. The tail bud protruded away from the body of the embryo (Figure 4F). At the 27-somites stage (Figure 4G), the length of the yolk extension became similar to that of the yolk ball. The elongating tail still curved ventrally, and the olfactory placodes could be seen anterior to the forebrain at the 31somites stage (Figure $4 \mathrm{H}$ ). At the 44-somites stage, the somitogenesis was complete (Figure $4 \mathrm{I}$ and $\mathrm{J}$ ) and the anterior brain of embryo displayed all major subdivisions.

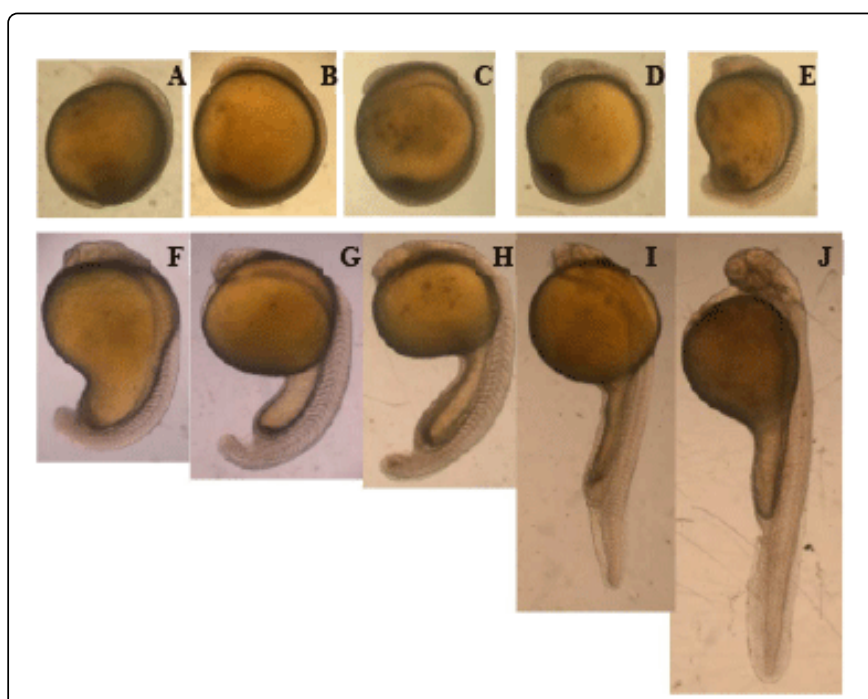

Figure 4: Embryonic development of $\mathrm{S}$. grahami during the segmentation period.

\section{Hatching and early larval period ( $96 \mathrm{~h}-168 \mathrm{~h})$}

Hatching in $S$. grahami was asynchronous, in that the embryos from a single clutch could hatch at irregular intervals. After completion of the last somites, the hatching period started at $96 \mathrm{HPF}$, the majority of the organ rudiments were formed, and the development of the jaw, the gill arches, and the pectoral fins was observed (Figure 5). Otoliths appeared as two conglomerates of small granules lying against the inner surface of each well-expanded otocyst. The rudiments of the pectoral fins appeared, and the yolk extension retained a distinctly cylindrical shape along most of its length, although the posterior end began to taper to assume a more conical appearance (Figure 5A). Then, the visible pigment granules appeared at the pigmented layer of the retina, and the brain was regionalized as forebrain, midbrain and hindbrain (Figure 5B). The yolk ball became markedly smaller. The development of the heart was complete, and it became difficult to view the heart in its entirety from any angle (Figure $5 \mathrm{C})$.

At the early larval period of $S$. grahami, most of the morphogenesis was complete (Figure 5D). The structure of brain was same as that of the adult. The newly hatched, free-floating larvae remained upsidedown and motionless at the bottom of the water. A urinary bladder was present at the posterior of the gut adjoining the pronephric tubules, and the swim bladder was observed for the first time dorsal to the liver in the whole-mount embryo. The mouth continued to grow out in an anterior and dorsal manner. The pigmentation increased on surface areas of the head and near the lateral line at the posterior part of the body. The larvae started to swim actively. In addition, the $S$. grahami larvae begin to show escape responses, respiration movements, and feeding desire. 


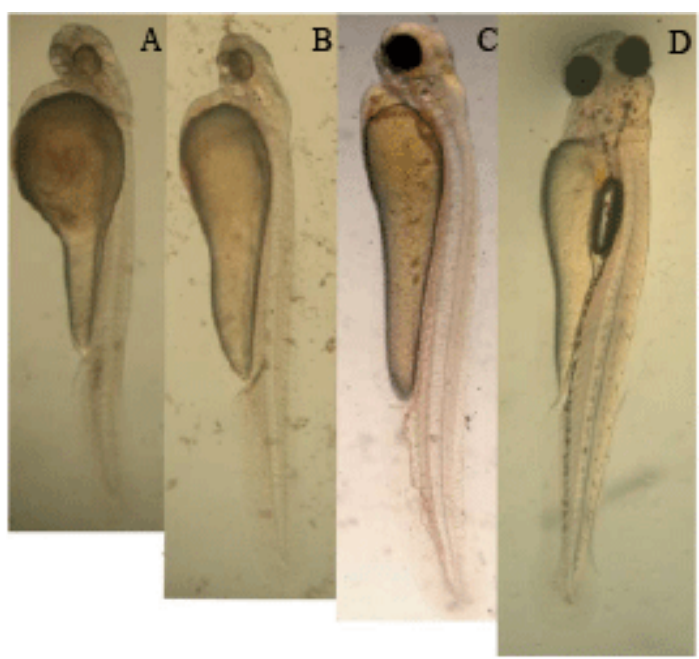

Figure 5: Development of S. grahami during the hatching and larval period.

\section{Discussion}

The various in fertilization rates reported in the literature may be caused by gamete quality or by different artificial fertilization methods used [8]. Studies on artificial fertilization methods S.grahami have been carried out and the suitable method has been used from 2007 to 2013, so S.grahami gamete quality may contribute to variety of the rate of fertilization, hatching and malformation. The use of high-quality gametes is of great importance for ensuring the production of viable larvae [18]. Fertilization, survival during incubation and hatching rates are most commonly used to assess egg quality, as these characteristics are highly correlated and strongly influenced by the female parent and the interaction between both parents [19]. In ex situ conservation of fish species, artificial fertilization success is largely dependent on broodstock management [14-20]. Thus, as broodstock management increased, the fertilization and hatching rates increased while the rate of malformation in hatching decreased. However, there was a drop of egg quality in 2009, which could be attributed to the injection of LHRH- $\mathrm{A}_{2}$ in most female and male parents. Additionally, egg quality gradually improved with the decreased use of oxytocin beginning in 2010. Therefore, we should focus on broodstock management but not LHRH-A 2 implantation for $S$. grahami artificial fertilization.

Our research presents a developmental series of $S$. grahami for the first time. The embryonic development of $S$. grahami is essentially similar to the processes described in D. rerio [11] and A. grahami [12]; however, $S$. grahami development is relatively slower than the development of $D$. rerio and $A$. grahami, most likely as a result of its larger yolk [3,21] and lower developmental water temperature [12]. Conversely, Onychostoma macrolepis, which belongs to the Barbinae, Cyprinidae, is also a troglophile species [22], with eggs and habitat temperature similar to those of $S$. grahami; however, its duration of embryonic development is $74 \mathrm{~h}$ [23], which is shorter than that of $S$. grahami. Embryos of the Mexican tetra Astyanax mexicanus, a modal cavefish, hatch $24 \mathrm{~h}$ after fertilization [24], much earlier than those of $S$. grahami. Therefore, this great different in embryonic development between $S$. grahami and $A$. mexicanus may caused by some unknown special adaptability to the Plateau cave environment [21].
The diameter of the zygote of $S$. grahami $(1.8-2.2 \mathrm{~mm})$ is larger than those of D. rerio $(0.5 \mathrm{~mm})$ [11], Oryzias latipes $(1.2 \mathrm{~mm})$ [25] and $A$. grahami $(1.4 \mathrm{~mm})[12]$ and is similar to those of other cavefish, such as O. macrolepis (2.3 mm) [23] and Amblyopsis rosae (2.2 mm) [21]. Cavefish usually have much larger eggs than their surface counterparts $[21,26]$, and most of the increased egg volume can be attributable to increased yolk size, although there is no difference in yolk composition [27].

All teleosts demonstrate a discoidal meroblastic cleavage pattern, wherein the large yolk volume restricts cell division to a small area at the animal pole [28]. The first divisions are vertical, and there is no cytoplasmic growth between early divisions, resulting in a decrease in blastomere size with each successive division [24-28]. Blastomeres share regular size and shape, so blastomere morphology has been used in most species as a predictive indicator of egg viability within a clutch [29]. However, inter- and intra-species variation exists within the general pattern. In $S$. grahami, horizontal stratification of the cell mass usually occurs at the sixth cleavage, between the 32- and 64-cell stage, just as in the developmental processes of D. rerio [11] and Gadus morhua [26]. In $O$. latipes, the first horizontal cleavage occurs at the fifth cleavage, between the 16- and 32-cell stages [30], and in Leucopsarion petersii, it occurs even earlier, between the 4- and 8-cell stages [31].

The number of somites provides a very useful method for determining the stage because it increases linearly during the segmentation period. Similar to O. latipes, D. rerio and A. grahami, the first somites of $S$. grahami are formed after the $100 \%$-epiboly stage. Curiously, there are obvious interspecies differences in final somite numbers within teleosts: $S$. grahami, 40-43 somites; Sinocyclocheilus xichouensis, 42-44 somites [32]; O. latipes, 30 somites [25]; D. rerio, 30-34 somites [11]; O. macrolepis, 46 somites; and Tor brevifilis brevifilis, 39 somites [23]. The final number of somites is usually correlated with vertebral number [33].

As a representative of the troglophile species, $S$. grahami seem to thrive in the cave environment despite the morphological characteristics of the species. In many cavefish, the eye structure is poorly developed and the number of taste buds is increased [27]; however, the eye structure of $S$. grahami is similar to those of surface fish, and the number of taste buds is far less than that of Sinocyclocheilus hyalinus, another cavefish. Thus, S. grahami is an interesting model to determine why troglophile species swim into caves and whether lower temperatures or cave conditions provide better spawning sites [31-34].

\section{Acknowledgments}

This study was supported by grants from the Basic Research Program of Yunnan Province (2012FB183) to X. F. Pan; the World Bank Dianchi Project (GEF-MSP grant No. TF051795), the Foundation of Development and Reformation Department of Yunnan Province, and the West Light Foundation, Chinese Academy of Sciences (292006312D11033) to J. X. Yang and X. Y. Chen.

\section{References}

1. Yue PQ, Chen YY (1998) China red data book of endangered animals: Pisces. Science Press, Beijing, China.

2. Wang S, Xie Y (2004) China Species Red List. Red List. Higher Education Press, Beijing, China. 
Citation: Pan XF, Wang XA, Ma L,Li ZY, Chen XY, Yang JX (2014) Artificial Fertilization and Embryonic Development of Sinocyclocheilus grahami (Regan) from Dianchi Lake, China. J Biodivers Biopros Dev 1: 101. doi:10.4172/2376-0214.1000101

Page 6 of 6

3. Chu XL, Chen YR (1978) Subspecies differentiation of Sinocyclocheilus. Curr Zool 24: 255-259.

4. Chu XL, Cui GH (1985) A revision of Chinese cyprinid genus Sinocyclocheilus with reference to the interspecific relationships. Acta Zootaxa Sinica 10: 435-441.

5. Chen SY, Zhang RD, Feng JG, Xiao H, Li WX, et al. (2009) Exploring factors shaping population genetic structure of the freshwater fish Sinocyclocheilus grahami (Teleostei, Cyprinidae). J Fish Biol 74: 1774-1786.

6. Billard R (1988) Artificial-Insemination and Gamete Management in Fish. Marine Behav Physiol 14: 3-21.

7. Billard R (1990) Artificial insemination in fish. Marshall's physiol reprod 2: $870-888$.

8. Chereguini O, de la Banda IG, Rasines I, Fernandez A (1999) Artificial fertilization in turbot, Scophthalmus maximus (L.): different methods and determination of the optimal sperm-egg ratio. Aquac Res 30: 319-324.

9. Yang JX, Pan XF, Li ZY (2007) Preliminary report on the successful breeding of the endangered fish Sinocyclocheilus grahami endemic to Dianchi Lake. Zool Res 28: 329-331.

10. Pan XF, Chen XY, Yang JX (2009a) Threatened fishes of the world: Sinocyclocheilus grahami (Regan) 1904 (Cyprinidae). Environ Biol Fishes 85: 77-78.

11. Kimmel CB, Ballard WW, Kimmel SR, Ullmann B, Schilling TF (1995) Stages of embryonic development of the zebrafish. Dev Dyn 203: 253-310.

12. Ma L, Pan XF, Wei YH, Li ZY, Li CC, et al. (2008) Embryonic stages and eye-specific gene expression of the local cyprinoid fish Anabarilius grahami in fuxian lake, China. J Fish Biol 73: 1946-1959.

13. Pan XF, Yang JX, Li ZY, Chen XY (2009b) Feeding changes and growth performance of Sinocyclocheilus grahami (Pisces, Barbinae) larvae and juveniles in farm environment. Zool Res 30: 433-437.

14. Pan XF, Yang JX, Chen XY, Li ZY (2011) [Broodstocks management, fecundity and the relationship between egg size and embryo survival ability of Sinocyclocheilus grahami]. Dongwuxue Yanjiu 32: 196-203.

15. da Rocha Perini V1, Sato Y, Rizzo E, Bazzoli N (2010) Biology of eggs, embryos and larvae of Rhinelepis aspera (Spix \& Agassiz, 1829) (Pisces: Siluriformes). Zygote 18: 159-171.

16. Boryshpolets S, Dzyuba B, Rodina M, Alavi SMH, Gela D, et al. (2011) Cryopreservation of sterlet (Acipenser ruthenus) spermatozoa using different cryoprotectants. J Appl Ichthyol 27:1147-1149.

17. Andrades JA, Becerra J, FernandezLlebrez P (1996) Skeletal deformities in larval, juvenile and adult stages of cultured gilthead sea bream (Sparus aurata L). Aquaculture 141: 1-11.
18. Kjørsvik E, Mangor-Jensen A, Holmefjord I (1990) Egg quality in fishes. Adv Mar biol 26: 71-113.

19. Saillant E, Chatain B, Fostier A, Przybyla C, Fauvel C (2001) Parental influence on early development in the European sea bass. J Fish Biol 58: 1585-1600.

20. Pan XF, Liu Q, Wang XA, Yang JX, Chen XY, et al. (2013) [Artificial propagation and embryonic development of Neolissochilus benasi]. Dongwuxue Yanjiu 34: 617-625.

21. Poulson TL, White WB (1969) The cave environment. Science 165 971-981.

22. Zhang CG (1986) On the ecological adaptation and geographical distribution of the barbine fish Varicorhinus (Scaphesthes) macrolepis (Bleeker). Acta Zool Sin 32: 266-272.

23. Cao WX, Chang JB, Qiao Y, Duan ZH (2007) Fish resources of early life history stages in Yangtze river. China Water Power Press, Beijing, China.

24. Langeland JA, Kimmel CB (1997) Fishes. In: Gilbert S.F., and A.M. Raunio. Embryology Constructing the Organism. Sinauer, Sunderland.

25. Iwamatsu $\mathrm{T}$ (2004) Stages of normal development in the medaka Oryzias latipes. Mech Dev 121: 605-618.

26. Huppop K, Wilkens H (1991) Bigger eggs in Subterranean Astyanax Fasciatus (Characidae, Pisces). J Zool Syst Evol Res 29: 280-288.

27. Jeffery WR (2001) Cavefish as a model system in evolutionary developmental biology. Dev Biol 231: 1-12.

28. Hall TE, Smith P, Johnston IA (2004) Stages of embryonic development in the Atlantic cod Gadus morhua. J Morphol 259: 255-270.

29. Shields R, Brown N, Bromage N (1997) Blastomere morphology as a predictive measure of fish egg viability. Aquaculture 155: 1-12.

30. Iwamatsu T (1994) Stages of normal development in the medaka Oryzias latipes. Zool Sci 11: 825-839.

31. Nakatsuji T, Kitano T, Akiyama N, Nakatsuji N (1997) Ice goby (shirouo), Leucopsarion petersii, may be a useful material for studying teleostean embryogenesis. Zool Sci 14: 443-448.

32. Pan XF, Li L, Yang JX, Chen XY (2013) [Sinocyclocheilus xichouensis, a new species of golden-line fish from the Red River drainage in Yunnan, China (Teleostei: Cypriniformes)]. Dongwuxue Yanjiu 34: 368-373.

33. Blaxter JHS (1969) Development: eggs and larvae. In: Hoar WS, Randall DJ (1stedn). Fish physiology, Reproduction and growth. Bioluminescence, pigments, and poisons. Academic Press, New York.

34. Zhao YH, Zhang CG (2009) Endemic fishes of Sinocyclocheilus (Cypriniformes: Cyprinidae) in China - species diversity, cave adaptation, systematics and zoogeography. Science Press, Beijing, China. 